\title{
Strategi Pengelolaan Dana Zakat BMT ItQan dalam Pengembangan UMKM
}

\author{
Yhogie Rhanwa Soegiar Jr, Nanih Machendrawaty, \& Yuliani \\ Jurusan Manajemen Dakwah, Fakultas Dakwah dan Komunikasi, \\ UIN Sunan Gunung Djati, Bandung \\ *Email:yhogierhanwa@student.uinsgd.ac.id
}

\begin{abstract}
ABSTRAK
Penelitian ini untuk mengetahui strategi pengelolaan BMT ItQan dalam mengembangkan UMKM di Cicahem Bandung. Penelitian ini menggunakan model dengan cara melakukan strategi pada produk, strategi harga, strategi distribusi dan strategi promosi selain itu strategi yang dilakukan adalah strategi pengelolaan dana zakat yang berkaitan dengan visi dan misi serta target pencapaian sebuah lembaga. Metode yang digunakan dalam penelitian ini adalah metode deskriptif analisis dengan pendekatan kualitatif. Implementasi BMT ItQan berkontribusi melalui program PERMATA (Pemberdayaan Ekonomi Masyarakat Dhuafa) melalui tiga bidang Program yaitu, Pembiayaan, Simpanan, dan Sinpanan Investasi. Hal ini merupakan salah satu bukti bahwa adanya peningkatan yang dilakukan oleh BMT ItQan dalam mengembangkan UMKM di Cicahem. Hasil dari penelitian ini bahwa BMT ItQan berhasil menjalankan tugasnya dalam pengembangan UMKM, karena telah merancang stratedi pengelolaan zakat dalam mengembangkan UMKM Cicahem kota bandung. Hal ini tercermin dari misi yang dilaksanakan oleh BMT ItQan terhadap peningkatan pemberdayaan UMKM. Dari proses survey, wawancara, pelatihan, pembinaan dan motivasi telah dilaksanakan sesuai strategi yang dirancang.
\end{abstract}

\section{Kata Kunci : Strategi, Zakat, UMKM}

\section{ABSTRACT}

This research is to find out the Management Strategy of BMT ItQan in developing MSMEs in Cicahem Bandung. This study uses a model by conducting strategies on products, price strategies, distribution strategies and promotion strategies, in addition to the strategy that is carried out is the management strategy of zakat funds related to the vision and mission as well as the achievement target of an institution. The method used in this study is a descriptive analysis method with a qualitative approach. The ItQan BMT implementation contributes through the PERMATA program (Community Economic Empowerment of Dhuafa) through three Program areas namely, Financing, Deposits, and Investment Sinpanan. This is one proof that there was an increase made by ItQan BMT in developing MSMEs in Cicahem. The results of this study that the ItQan BMT succeeded in carrying out their duties in the development of 
MSMEs, because they had designed the management of zakat in developing the Cicahem UMKM in Bandung. This is reflected in the mission carried out by the ItQan BMT towards improving the empowerment of MSMEs. From the survey process, interviews, training, coaching and motivation have been carried out according to the strategies designed.

Keywords: Strategy, Zakat, UMKM

\section{PENDAHULUAN}

Ekonomi Islam dibangun atas dasar agama Islam, karenanya ia merupakan bagian tak terpisahkan (integral) dari agama Islam. Sebagai derivasi dari agama islam, ekonomi islam akan mengikuti agama Islam dalam berbagai aspeknya. (Pusat Pengkajian dan pengembangan Ekonomi Islam, 2008:13)

Di dalam sebuah sistem ekonomi terdapat unsur yang keberadaannya menjadi karakteristik dari sistem ekonomi yang bersangkutan. Unsur tersebut adalah produksi, distribusi dan konsumsi. Dalam produksi terdapat empat faktor yang paling penting yaitu faktor alam, tenaga kerja, modal dan manajemen. (Djazuli dan Yadi Janwari, 2002:26).

Keempat faktor dalam produksi tersebut saling terkait antara satu dan lainnya. Produksi memerlukan faktor alam atau yang biasa disebut dengan bahan baku, bahan baku harus dikelola agar bisa menjadi barang yang dapat diproduksi. Namun, dalam proses produsi, yang tidak kalah pentingnya adalah faktor modal, karena apabila tidak ada modal maka produsen tidak akan bisa membeli bahan baku, dan juga tidak bisa membayar upah tenaga kerja. Ketiga faktor tersebut dilengkapi dengan faktor ke empat yaitu manajemen, karena jika ketiga faktor tersebut ada namun manajemennya tidak berjalan baik, maka usaha yang dilakukan pun tidak akan berjalan dengan baik. Manajemen diatur sedemikian. Selain itu zakat mempunyai kedudukan yang penting dalam struktur ekonomi keagamaan dari mekanisme keuanga Islam.Persoalan terbesar UMKM adalah kesulitan mengakses permodalan. Dampak dari kesulitan dalam mengakses permodalan adalah banyak UMKM yang masih menggunakan jasa pelepas uang bagi pengembangan usahanya. Karena pelepas uang memberikan kemudahan dalam persyaratan pangajuan pembiayaan. Pelepas uang tersebut adalah rentenir, yang dalam prakteknya meminjamkan uang kepada masyarakat yang membutuhkan dana dengan tidak melalui proses yang rumit. Namun rentenir tersebut menetapkan bunga yang justru semakin mempersulit si peminjam uang. Dalam Islam, jelas praktek rentenir tersebut tidak dibenarkan karena dapat dipersamakan dengan riba. Disinilah peran lembaga zakat sangat diperlukan, untuk membantu wirausahawan agar mendapatkan modal yang halal untuk menjalanka usahanya kembali atau memulai usaha baru. Dengan bantuan modal yang diberikan akan terbukanya usaha baru yang akan berdampak pada terbukanya lapangan pekerjaan baru pula.

Adanya pembiayaan yang diberikan oleh lembaga zakat untuk Usaha Mikro, Kecil dan Menengah dapat membantu mereka agar terhindar dari praktek riba yang menjerat mereka (Setiawan, 2012). 
Sala satu lembaga zakat yang menyediakan pembiayaan untuk UMKM adalah Baitul Mal wa Tamwil (BMT). Baitul Mal wa Tamwil (BMT) adalah balai usaha mandiri terpadu dengan kegiatan mengembangka usaha-usaha produktif dan investasi dalam meningkatkan kualitas kegiatan ekonomi pengusaha kecil bawah dan menengah dengan antara lain mendorong kegiata menabung dan menunjang pembiayaan kegiatan ekonominya, selain itu, BMT juga bisa menerima titipan zakat, infak dan sadaqah, serta menyalurkannya sesuai dengan peraturan dan amanatnya. Memberikan pembiayan untuk UMKM diperlukan strategi yang tepat agar BMT dapat menyalurkan pembiayaan tersebut pada usaha yang tepat dan mendapatkan keuntungan dari hasil kerjasama yang dilakukan.

BMT ItQan merupakan salah satu lembaga keuangan mikro yang berada di Cicaheum Kota Bandung. BMT ini merupakan mitra dari para pengusaha UMKM tepatnya UMKM yang bergerak di bidang perdagangan, seperti pedagangpedagang di pasar tradisional serta toko-toko sembako yang berada di lingkungan Baitul Mal wat Tamwil Itqan (BMT Itqon).

BMT ItQan ini baru berdiri pada tahun 2007, namun setiap tahunnya selalu mengalami perkembangan yang signifikan. Sampai bulan April 2016 ini tercatat jumlah nasabahnya sudah mencapai 500 orang.

Perkembangan yang terjadi menunjukan bahwa BMT ItQan memiliki strategi dalam melakukan aktifitasnya, dan telah menjalankan fungsinya untuk mengembangkan UMKM di kawasan Cicaheum. Di latar belakangi penjelasan tersebut di atas, maka penulis tertarik untuk mempelajari dan mengkaji lebih jauh tentang strategi yang dilakukan oleh BMT ItQan dalam mengembangkan Usaha Mikro, Kecil dan Menengah (UMKM).

Strategi adalah langkah-langkah yang harus dijalankan oleh suatu perusahaan untuk mencapai tujuan. Kadang-kadang langkah yang harus dihadapi terjal dan berliku-liku, namun ada pula langkah yang relatif mudah. Di samping itu, banyak rintangan atau cobaan yang dihadapi untuk mencapai tujuan. Oleh karena itu, setiap langkah harus dijalankan secara hati-hati dan terarah.

Definisi strategi di atas dapat disimpulkan bahwa yang dimaksud strategi adalah langkah-langkah atau rencana yang harus dijalankan secara cermat mengenai kegiatan untuk mencapai sasaran khusus. Pengertian strategi secara umum dan khusus sebagai berikut.

Menurut Soekanto, Pengertian Pengelolaan adalah suatu proses yag dimulai dari proses perencanaan, pengaturan, pengawasan, penggerak sampai dengan proses terwujudnya tujuan.

Menurut Prajudi, Pengertian Pengelolaan ialah pengendalian dan pemanfaatan semua faktor sumber daya yang menurut suatu perencana diperlukan untuk penyelesaian suatu tujuan kerja tertentu.

Berdasarkan pengertian pengelolaan di atas, dapat disimpulkan bahwa Pengertian Pengelolaan yaitu bukan hanya melaksanakan suatu kegiatan, yang meliputi fungsi-fungsi manajemen, seperti perencanaan, pelaksanaan dan pengawasan untuk mencapai tujuan secara efektif dan efisien. 
Menurut undang-undang No 20 Tahun 2008, Usaha mikro adalah usaha produktif milik orang perorangan dan/atau badan usaha perorangan yang memenuhi kriteria sebagai berikut : (a) Memiliki kekayaan bersih paling banyak Rp. 50.000.000 (lima puluh juta rupiah) tidak termasuk tanah dan bangunan tempat usaha; atau (b) Memiliki hasil penjualan tahunan paling banyak Rp. 300.000.000 (tiga ratus juta rupiah). Usaha kecil diatur dalam Undang-Undang Nomor 9 Tahun 1995 tentang Usaha Kecil. Seiring dengan kebutuhan, percepatan pertumbuhan perekonomian dan pembangunan hukum, maka Undang-Undang Usaha Kecil diganti dengan Undang-Undang Nomor 20 Tahun 2008 tentang Usaha Mikro Kecil dan Menengah yang lebih memperjelas dan mempertegas ketentuan Undang-Undang Usaha Kecil.

BMT adalah kependekan kata Balai Usaha Mandiri Terpadu atau Baitul Mal wat Tamwil, yaitu lembaga keuangan mikro (LKM) yang beroperasi berdasarkan prinsip-prinsip syariah. BMT sesuai namanya terdiri dari dua fungsi utama, yaitu :

Baitul Tamwil (rumah pengembangan harta), melakukan kegiatan pengembangan usaha-usaha produktif dan investasi dalam meningkatkan kualitas ekonomi pengusaha mikro dan kecil dengan antara lain mendorong kegiatan menabung dan menunjang pembiayaan kegiatan ekonomi.

Baitul Mal(rumah harta), menerima titipan zakat, infak dan sedekah serta mengoptimalkan distribusinya sesuai dengan peraturan dan amanahnya.(Soemitra, 2009: 447)

Pola pengembangan institusi keuangan ini diadopsi dari Bayt al-mal yang pernah dan sempat tumbuh dan berkembang pada masa Nabi SAW dan Khulafa al-Rasyidin. Oleh karena itu, keberadaan BMT selain bisa dianggap sebagai media penyalur pendayagunaan harta ibadah seperti zakat, infaq dan shadaqah, juga bisa dianggap sebagai institusi yang bergerak di bidang investasi yang bersifat produktif seperti layaknya bank. (Djazuli dan Yadi Janwari,2002: 183)

Oleh karena itu, selain berfungsi sebagai lembaga keuangan BMT juga bisa berfungsi sebagai lembaga ekonomi. Sebagai lembaga keuangan ia bertugas menghimpun dana dari masyarakat (anggota BMT) dan menyalurkan dana dari masyarakat (anggota BMT). Sebagai lembaga ekonomi ia juga berhak melakukan kegiatan ekonomi, seperti perdagangan, industri dan pertanian.

Lokasi penelitian penulis di BMT ItQan Jalan Padasuka, 160 Cicaheum Kota Bandung. Penelitian ini untuk mengetahui strategi program pengelolaan dana zakat BMT ItQan dalam mengembangkan UMKM di Cicaheum Kota Bandung, implementasi program pengelolaan dana zakat dana Zakat pada BMT ItQan, dan hasil implementasi program pengelolaan dana zakat dana Zakat pada BMT ItQan?

\section{METODE PENELITIAN}

Jenis penelitian ini adalah kualitatif, karena dapat digolongkan ke dalam deskriptif dengan pendekatan studi kasus yaitu untuk melakukan pengukuran yang 
Yhogie Rhanwa Soegiar Jr, Nanih Machendrawaty, \& Yuliani

cermat dan sistematik terhadap peristiwa tertentu dengan cara menafsirkan data yang telah ada dengan tanpa hipotesis dan tetap mempertahankan keutuhan dari objek penelitian yang terintegrasi.

Objek penelitian ini ditetapkan secara khusus pada BMT ItQan Cicaheum Kota Bandung, dan diarahkan untuk mengumpulkan data yang mendukung untuk menjawab permasalahan yang telah diungkapkan di atas. Penelitian ini khususnya diarahkan pada strategi BMT ItQan dalam mengembangkan UMKM di Cicaheum Kota Bandung.

Penulis menggunakan jenis data primer dan sekunder Data primer diperoleh melalui pengamatan kegiatan operasional dalam wawancara, BMT ItQan Cicaheum Kota Bandung. Data sekunder diambil dari dokumentasi perusahaan. Khususnya pada BMT ItQan Cicaheum Kota Bandung.

Observasi (data primer) yang dilakukan penulis yaitu dengan cara mengadakan pengamatan secara langsung pada objek yang diteliti yaitu pada BMT ItQan Cicaheum Kota Bandung. Data yang diperoleh mencakup beberapa aspek dari segi ekonomi, religius, pendidikan dan teknis yang meliputi situasi lokasi dan keamanan tempat penelitian.

Wawancara (data primer) yaitu penulis mengadakan wawancara secara langsung tentang data internal perusahaan dengan pimpinan BMT ItQan Cicaheum Kota Bandung yang mewakili objek yang diteliti. Data yang diperoleh berupastrategi BMT ItQan dalam mengembangkan UMKM di Cicaheum Kota Bandung.

Dokumentasi (data sekunder) yaitu proses untuk memperoleh keterangan untuk tujuan penelitian yang berasal dari data yang berbentuk arsip (dokumen) yang dimiliki oleh BMT ItQan, buku, majalah, dan baik melalui internet maupun media lainnya. Data yang diperoleh berupa struktur organisasi, personalia, pemasaran dan operasional.

Analisa dilakukan setelah data-data yang dibutuhkan dalam penelitian ini terkumpul. Proses analisa dimulai dari membaca, mempelajari, dan menelaah data yang didapat mengenai strategi BMT ItQan dalam mengembangkan UMKM di Cicaheum Kota Bandung. Selanjutnya dari proses analisa tersebut, penulis mengambil kesimpulan dalam masalah yang bersifat umum kepada masalah yang bersifat khusus deduktif.

\section{HASIL DAN PEMBAHASAN}

Pada mulanya BMT itQan didirikan Tahun 2007. Beberapa orang merupakan kelompok pengajian di Bandung, berinisiatif membentuk suatu amal usaha bersama yang bertujuan mengimplementasi nilai-nilai kebenaran Agama Islam. Kemudian amal usaha tersebut terimplementasi dalam bidang ekonomi, sosial, pendidikan dan kesehatan.

Baitul Maal wat Tamwiil (BMT), salah satu bentuk amal usaha yang dipilih. Karena dalam BMT jenis usaha yang dapat dikembangkan diharapkan dapat mengangkat perekonomian (baitut tamwiil) sekaligus juga dapat mendayagunakan 
dana sosial Zakat, Infaq, Shodaqoh, Wakaf maupun Hibah (ZISWAH) untuk kepentingan kaum dhuafa / ummat.

Pemberdayaan kaum dhuafa merupakan misi utama BMT ItQan, sejalan dengan hadits Nabi Muhammad SAW : "khairunnaas 'anfauhum linnaas---sebaikbaik manusia adalah yang paling banyak manfaatnya buat manusia lainnya”.

Proses kegiatan BMT ItQan dimulai dari mengelola sebagian kecil dana zakat dan membuat payment point listrik sebagai sumber utama untuk menggaji karyawan yang awalnya hanya 1 orang teller. Dengan berkembangnya kepercayaan dari masyarakat maka BMT ItQan sejak awal 2008 mulai menggulirkan pembiayaan untuk usaha mikro dengan jumlah pinjaman awal berkisar Rp. 200 ribu sampai Rp. 1 juta. Dan terus berkembang sampai tahun-tahun berikutnya.

Dengan semakin berkembangnya amal usaha BMT ITQAN, maka secara profesional BMT ITQAN terbagi menjadi lembaga yang memiliki dua badan hukum. Badan hukum Koperasi Syariah sebagai aktivitas Baitut Tamwil dan Yayasan Baitul Maal itQan sebagai pengelola dana ummat (ZISWAH), CSR dan sebagianya.

Sehingga pada tanggal 23 Mei 2013 Baitul Maal itQan terdaftar sebagai Yayasan Sosial-Keagamaan melalui Notaris Deni Subarno, SH dan secara resmi menjadi Yayasan Baitul Maal itQan berdasarkan Surat Keputusan KEMENKUMHAM Nomor : AHU-2192.AH.01.04.Tahun 2014.

Program yang ada di Lembaga BMT ItQan khususnya dalam penegembangan Ekonomi yaitu, Pemberdayaan Ekonomi Masyarakat Dhuafa (PERMATA). Pemberdayaan Ekonomi Masyarakat Dhuafa terbagi menjadi tiga yaitu, Pemberian Modal Usaha, Produk Simpanan BMT, dan Simpanan Investasi.

\section{Strategi Program dan Pengelolaan dana Zakat BMT ItQan dalam Mengembangkan UMKM Cicaheum Kota Bandung}

PERMATA atau (Pemberdayaan Ekonomi Masyarakat Dhuafa), diperuntukan bagi masyarakat kecil yang lemah dari segi ekonomi. Program PERMATA diharapkan dapat membantu masyarakat dalam mengembangkan usaha dan menggerakkan roda ekonomi keluarga.

Penerima manfaat program ini yaitu para pedagang dan pelaku usaha kecil yang dapat dibina dan diberikan modal usaha, menuju masyarakat yang berdaya demi memenuhi kebutuhan sendiri, keluarga maupun orang lain. Sehingga, program ini dapat bermanfaat untuk kemaslahatan ummat, memandirikan dan memberdayakan. (a). Meningkatkan semangat berwirausaha (b). Memberi keterampilan dan ilmu kewirausahaan (c). Meningkatkan kesolehan para penerima manfaat (d). Memandirikan dan menyejahterakan kehidupan penerima manfaat (e). Menyetak Pedagang Muslim yang soleh. Mengurangi tingkat kemiskinan, dengan memberikan pelatihan keterampilan, serta pendampingan usaha. Meningkatkan peran dunia usaha (private sector) terutama dalam pengurangan tingkat pengangguran dan kemiskinan. Adanya model inkubasi usaha yang dapat dimanfaatkan untuk menjadi stimulan pemodelan kemandirian bagi masyarakat 
Yhogie Rhanwa Soegiar Jr, Nanih Machendrawaty, \& Yuliani

dhuafa disekitar tempat tinggal. Inkubasi usaha pertama sifatnya sebagai stimulan produktivitas untuk melahirkan unit-unit usaha dan dapat dimanfaatkan secara jangka panjang sehingga jumlah penerima manfaat akan semakin banyak. Memberi kesempatan kepada masyarakat tidak mampu mendapatkan keahlian sesuai potensi dan usahanya. Meningkatkan kepercayaan diri masyarakat tidak mampu untuk mandiri. Membuka akses lapangan pekerjaan.

Setelah mengikuti Program ini diharapkan Penerima Manfaat dapat lebih sejahtera, dan memiliki keterampilan Berakhlak soleh, dan meningkat ilmu agamanya Memajukan perekonomian negara, dengan berwirausaha Menjadi mandiri dan memiliki kemampuan berzakat (muzaki) Membuka peluang usaha baru (Sanusi, 2016).

Pada Program Pemberdayaan Ekonomi Masyarakat Dhuafa membagi produknya kedalam tiga macam, yaitu produk pembiayaan, produk simpanan, dan simpanan investasi. Adapun jenis produk dan mekanismenya adalah sebagai berikut : pertama, Produk Pembiayaan Bmt ItQan. Pembiayaan yang diberikan untuk penambahan modal kerja usaha seperti untuk pembelian bahan baku, penambahan persediaan, peningkatan omzet dll. Pembiayaan ini mempunyai dua akad yaitu akad Mudharabah (bagi hasil) dan akad Murabahah (jual beli). Akad Mudharabah Pembiayaan dengan akad mudharabah adalah pembiayaan yang diperuntukan bagi pengusaha mikro sebagai tambahan modal usaha investasi. Pembiayaan ini diutamakan untuk para pedagang kecil.

Adapun persyaratan dari pembiayaan mudharabah ini adalah memiliki usaha yang telah berjalan minimal tiga bulan, mengisi formulir permohonan, fotokopi KTP, dan bersedia disurvei ke rumah dan tempat usaha. Nasabah harus memiliki usaha yang telah berjalan minimal tiga bulan karena dalam tiga bulan sejak memulai usaha, dapat terlihat perkembangan usaha yang dijalani, apakan menguntungkan atau kurang menguntungkan. BMT tidak memberikan pembiayaan untuk nasabah yang belum memiliki usaha yang telah berjalan, karena dikhawatirkan dana yang diberikan tidak diperuntukan untuk usaha yang dimaksud dan dikhawatirkan usaha yang dijalani tidak tepat.

Mengisi formulir pemohonan pembukaan, dalam formulir tersebut ada banyak hal yang harus diisi oleh nasabah yang akan mengajukan pembiayaan antara lain adalah jenis usaha yang akan dibiayai, selain itu dijelaskan pula tentang persentase bagi hasil antara nasabah dengan BMT ItQan, dan lamanya waktu pengembalian pembiayaan tersebut serta jumlah cicilan yang akan rutin dibayarkan sesuai waktu yang telah ditentukan sendiri oleh nasabah.

Fotokopi KTP diperlukan sebagai bukti bahwa nasabah tersebut adalah benar tercatat sebagai warga Negara Indonesia yang bertempat tinggal di wilayah dimana tertera pada KTP tersebut.

Nasabah yang telah mengajukan pembiayaan kepada BMT ItQan tidak langsung mendapatkan pembiayaan langsung di hari dimana nasabah mengajukan permohonan tapi dilakukan survei terlebih dahulu dan nasabah harus bersedia disurvei ke rumah dan tempat usahanya. Hal ini untuk 
membuktikan bahwa apakah benar nasabah tersebut bertempat tinggal sesuai dengan KTP yang ada dan apakah benar nasabah tersebut memiliki usaha yang dimaksud. Survei ke tempat usaha juga untuk mengetahui apakah usaha tersebut layak untuk diberikan pembiayaan atau tidak.

Nasabah yang mengajukan pembiayaan, banyak hal yang akan dipertimbangkan oleh pihak BMT setelah mensurvei tempat usaha yang akan dibiayai, antara lain adalah apakah jenis usaha tersebut sudah sesuai dengan syariat islam, jika usahanya adalah berdagang maka apakah barang yang didagangkan tersebut diharamkan oleh syariat Islam atau tidak, seperti menjual minuman keras, menjual daging babi dan lain sebagainya. Jika diharamkan maka pembiayaan tidak akan diberikan. Selain itu apakah tempat yang dijadikan untuk usaha sesuai dengan pasar yang dituju, strategis atau tidak. BMT juga mempertimbangan aspek resiko, seberapa besar resiko yang akan terjadi jika pembiayaan tersebut diberikan.

Setelah survei dilakukan maka pihak BMT akan melakukan rapat dengan mempertimbangkan aspek-aspek yang telah didapat saat melakukan survei. Jika dinyatakan layak mendapat pembiayaan maka BMT akan memberitahu nasabah untuk kemudian pembiayaan itu dicairkan.

Untuk menghindari terjadinya kerugian atau wanprestasi, maka diperlukan jaminan dari pembiayaan tersebut. Jaminan tersebut ditentukan berdasarkan jumlah pembiayaan yang diajukan oleh nasabah. Jika pembiayaan yang diajukan di atas Rp. 2.000.000,- maka jaminan yang diminta adalah BPKB atau barang berharga yang memiliki nilai jual. Jika pembiayaan yang diajukan dibawah Rp. 2.000.000,- maka jaminannya hanyalah buku nikah.

Keuntungan yang diperoleh oleh pihak BMT didapat dari bagi hasil yang besarnya telah disepakati di awal akad. Besarnya bagi hasil tersebut dinyatakan dalam bentuk persentase bukan dalam bentuk nominal tertentu.

Pengembalian pinjaman tersebut dapat dicicil sesuai dengan yang telah ditentukan oleh nasabah, bisa perhari, perminggu atau perbulan. Bagi hasil tersebut dibayarkan bersamaan dengan cicilan pembayaraan pinjaman. Pembiayaan yang diberikan untuk membeli alat-alat investasi, seperti, mesinmesin, alat produksi, kendaraan operasional dan lain-lain. Akad yang di gunakan yaitu Akad Murabahah Pembiayaan dengan akad murabahah adalah kerja sama yang dilakukan antara BMT dan nasabahnya. Kerjasama tersebut adalah dalam hal jual beli. Pembiayaan tersebut diberikan kepada nasabah dalam rangka pemenuhan kebutuhan produksi.

Pembiayaan yang diberikan untuk penambahan modal kerja usaha seperti untuk pembelian bahan baku, penambahan persediaan, peningkatan omzet dll. Pembiayaan ini mempunyai dua akad yaitu akad Mudharabah (bagi hasil) dan akad Murabahah (jual beli). Pembiayaan dengan akad mudharabah adalah pembiayaan yang diperuntukan bagi pengusaha mikro sebagai tambahan modal usaha investasi. Pembiayaan ini diutamakan untuk para pedagang kecil.

Adapun persyaratan dari pembiayaan mudharabah ini adalah memiliki 
usaha yang telah berjalan minimal tiga bulan, mengisi formulir permohonan, fotokopi KTP, dan bersedia disurvei ke rumah dan tempat usaha. Nasabah harus memiliki usaha yang telah berjalan minimal tiga bulan karena dalam tiga bulan sejak memulai usaha, dapat terlihat perkembangan usaha yang dijalani, apakan menguntungkan atau kurang menguntungkan. BMT tidak memberikan pembiayaan untuk nasabah yang belum memiliki usaha yang telah berjalan, karena dikhawatirkan dana yang diberikan tidak diperuntukan untuk usaha yang dimaksud dan dikhawatirkan usaha yang dijalani tidak tepat. Mengisi formulir pemohonan pembukaan, dalam formulir tersebut ada banyak hal yang harus diisi oleh nasabah yang akan mengajukan pembiayaan antara lain adalah jenis usaha yang akan dibiayai, selain itu dijelaskan pula tentang persentase bagi hasil antara nasabah dengan BMT ItQan, dan lamanya waktu pengembalian pembiayaan tersebut serta jumlah cicilan yang akan rutin dibayarkan sesuai waktu yang telah ditentukan sendiri oleh nasabah. Fotokopi KTP diperlukan sebagai bukti bahwa nasabah tersebut adalah benar tercatat sebagai warga Negara Indonesia yang bertempat tinggal di wilayah dimana tertera pada KTP tersebut. Nasabah yang telah mengajukan pembiayaan kepada BMT ItQan tidak langsung mendapatkan pembiayaan langsung di hari dimana nasabah mengajukan permohonan tapi dilakukan survei terlebih dahulu dan nasabah harus bersedia disurvei ke rumah dan tempat usahanya. Hal ini untuk membuktikan bahwa apakah benar nasabah tersebut bertempat tinggal sesuai dengan KTP yang ada dan apakah benar nasabah tersebut memiliki usaha yang dimaksud. Survei ke tempat usaha juga untuk mengetahui apakah usaha tersebut layak untuk diberikan pembiayaan atau tidak. Nasabah yang mengajukan pembiayaan, banyak hal yang akan dipertimbangkan oleh pihak BMT setelah mensurvei tempat usaha yang akan dibiayai, antara lain adalah apakah jenis usaha tersebut sudah sesuai dengan syariat islam, jika usahanya adalah berdagang maka apakah barang yang didagangkan tersebut diharamkan oleh syariat Islam atau tidak, seperti menjual minuman keras, menjual daging babi dan lain sebagainya. Jika diharamkan maka pembiayaan tidak akan diberikan. Selain itu apakah tempat yang dijadikan untuk usaha sesuai dengan pasar yang dituju, strategis atau tidak. BMT juga mempertimbangan aspek resiko, seberapa besar resiko yang akan terjadi jika pembiayaan tersebut diberikan.

Setelah survei dilakukan maka pihak BMT akan melakukan rapat dengan mempertimbangkan aspek-aspek yang telah didapat saat melakukan survei. Jika dinyatakan layak mendapat pembiayaan maka BMT akan memberitahu nasabah untuk kemudian pembiayaan itu dicairkan.

Untuk menghindari terjadinya kerugian atau wanprestasi, maka diperlukan jaminan dari pembiayaan tersebut. Jaminan tersebut ditentukan berdasarkan jumlah pembiayaan yang diajukan oleh nasabah. Jika pembiayaan yang diajukan di atas Rp. 2.000.000,- maka jaminan yang diminta adalah BPKB atau barang berharga yang memiliki nilai jual. Jika pembiayaan yang diajukan 
dibawah Rp. 2.000.000,- maka jaminannya hanyalah buku nikah.

Keuntungan yang diperoleh oleh pihak BMT didapat dari bagi hasil yang besarnya telah disepakati di awal akad. Besarnya bagi hasil tersebut dinyatakan dalam bentuk persentase bukan dalam bentuk nominal tertentu.

Pengembalian pinjaman tersebut dapat dicicil sesuai dengan yang telah ditentukan oleh nasabah, bisa perhari, perminggu atau perbulan. Bagi hasil tersebut dibayarkan bersamaan dengan cicilan pembayaraan pinjaman.

Pembiayaan yang diberikan untuk membeli alat-alat investasi, seperti, mesin-mesin, alat produksi, kendaraan operasional dan lain-lain. Akad yang di gunakan yaitu Akad Murabahah Pembiayaan dengan akad murabahah adalah kerja sama yang dilakukan antara BMT dan nasabahnya. Kerjasama tersebut adalah dalam hal jual beli. Pembiayaan tersebut diberikan kepada nasabah dalam rangka pemenuhan kebutuhan produksi. Murabahah merupakan akad jual beli dimana pembeli mengetahui harga barang dan besar keuntungan yang diinginkan oleh penjual. Keuntungan tersebut dapat dinyatakan dalam nominal tertentu atau dalam bentuk persentase dari harga pembeliannya. Untuk persyaratan serta mekanisme permohonan pembiayaan ini hampir sama dengan pengajuan pembiayaan murabahah. Namun, dalam pembiayaan murabahah ini keuntungan yang diperoleh pihak BMT ditentukan di awal, dan telah disepakati bersama.

Pembiayaan ini diberikan kepada nasabah dalam rangka pemenuhan kebutuhan produksi karena itu, nasabah yang mengajukan pembiayaan ini pun harus memiliki usaha yang telah berjalan. Semua nasabah pembiayaan murabahah ini memiliki usaha, biasanya mereka meminta BMT untuk membelikan mesin untuk produksi atau barang lain yang terkait dengan bahan baku produksi.

Pembiayaan yang diberikan untuk keperluan konsumtif seperti : pembelian kendaraan, pembelian alat komunikasi, uang sekolah dll.

Pembiayaan ini biasanya untuk biaya pendidikan anak sekolah. Nasabah yang ingin memasukan sekolah anaknya namun tidak memiliki dana untuk biaya masuk tersebut dapat pengajukan pembiayaan kepada BMT.

Karena pembiayaan ini merupakan pembiayaan konsumtif, dimana dana yang diberikan bukan untuk modal usaha yang dapat menghasilkan, maka pada pambiayaan ini tidak dikenakan bagi hasil. Namun jika nasabah ingin memberikan balas jasa dari hasil dana yang dipinjam, maka pihak BMT menerimanya dan besarnya pun tidak ditentukan oleh pihak BMT.

Pengembalian cicilan pembiayaan dilakukan dengan cara pihak BMT ItQan menagihnya langsung ketempat berjualan pedagang yang meminjam. Hal ini untuk mempermudah pedagang yang meminjam agar pedagang tersebut tetap bisa berjualan tanpa harus meninggalkan dagangannya hanya untuk membayar cicilan ke kantor BMT ItQan. Dari semua produk yang ada di BMT ItQan, semuanya 
Yhogie Rhanwa Soegiar Jr, Nanih Machendrawaty, \& Yuliani

bertujuan untuk mempermudah para pengusaha UMKM dalam menjalankan usahanya. Nasabah pada BMT ItQan ini sebagian besar merupakan para pedagang di daerah Cicaheum.

Murabahah merupakan akad jual beli dimana pembeli mengetahui harga barang dan besar keuntungan yang diinginkan oleh penjual. Keuntungan tersebut dapat dinyatakan dalam nominal tertentu atau dalam bentuk persentase dari harga pembeliannya.

Untuk persyaratan serta mekanisme permohonan pembiayaan ini hampir sama dengan pengajuan pembiayaan murabahah. Namun, dalam pembiayaan murabahah ini keuntungan yang diperoleh pihak BMT ditentukan di awal, dan telah disepakati bersama.

Pembiayaan ini diberikan kepada nasabah dalam rangka pemenuhan kebutuhan produksi karena itu, nasabah yang mengajukan pembiayaan ini pun harus memiliki usaha yang telah berjalan. Semua nasabah pembiayaan murabahah ini memiliki usaha, biasanya mereka meminta BMT untuk membelikan mesin untuk produksi atau barang lain yang terkait dengan bahan baku produksi.

Pembiayaan yang diberikan untuk keperluan konsumtif seperti : pembelian kendaraan, pembelian alat komunikasi, uang sekolah dll.

Pembiayaan ini biasanya untuk biaya pendidikan anak sekolah. Nasabah yang ingin memasukan sekolah anaknya namun tidak memiliki dana untuk biaya masuk tersebut dapat pengajukan pembiayaan kepada BMT.

Karena pembiayaan ini merupakan pembiayaan konsumtif, dimana dana yang diberikan bukan untuk modal usaha yang dapat menghasilkan, maka pada pambiayaan ini tidak dikenakan bagi hasil. Namun jika nasabah ingin memberikan balas jasa dari hasil dana yang dipinjam, maka pihak BMT menerimanya dan besarnya pun tidak ditentukan oleh pihak BMT. Pengembalian cicilan pembiayaan dilakukan dengan cara pihak BMT ItQan menagihnya langsung ketempat berjualan pedagang yang meminjam. Hal ini untuk mempermudah pedagang yang meminjam agar pedagang tersebut tetap bisa berjualan tanpa harus meninggalkan dagangannya hanya untuk membayar cicilan ke kantor BMT ItQan.

Dari semua produk yang ada di BMT ItQan, semuanya bertujuan untuk mempermudah para pengusaha UMKM dalam menjalankan usahanya. Nasabah pada BMT ItQan ini sebagian besar merupakan para pedagang di daerah Cicaheum.

Simpanan Pokok (SIMPOK), Simpanan Wajib (SIMWA),Suka Rela (SIRELA) ItQan, Simpanan Berjangka (SIJAKA) ItQan,Simpanan Khusus (SIMSUS),Simpanan Investasi Untung bersama simpanan investasi di Koperasi Syariah bmt itQan. Anggota yang aktif mendapatkan : Mendapatkan Bagi Hasil hingga setara 12\% .Mendapatkan Taawun/ asuransi Kesehatan Rp 200.000,,Mendapatkan Taawun/ asuransi Menikah Rp 500.000,-, Mendapatkan Taawun/ asuransi Melahirkan Rp. 1.000.000, Mendapatkan 
Taawun/ asuransi Jiwa Rp 2.500.000,-Gratis Asuransi Simpanan

Adapun Metodologi Pembiayaan dan sasaran Nasabah yang di utamakan yaitu sesuai dengan visi dan misi, sasaran nasabah BMT ItQan adalah mempunyai kriteria sebagai berikut : Diutamakan Wanita, karena wanita/ibu-ibu lebih bertanggung jawab dalam pengelolaan keuangan keluarga. status Keluarga Pra Sejahtera dengan ukuran indeks pendapatan per kapita keluarga $<$ Rp. 300 ribu per bulan Mempunyai usaha atau akan menjalani usaha mikro dengan pembiayaan pertama maksimal Rp. 1 juta

Metodologi Pembiayaan : Survey Wilayah.,Pertemuan Umum.,Targeting.Uji Kelayakan,Latihan wajib kumpulan, Ujian Pengesahan Kumpulan, Pembentukan Center, Center Meeting/Transaksi/Pembinaan.

\section{Implementasi Program Pengelolaan Dana Zakat Dalam Meningkatkan UMKM Cicaheum Kota Bandung}

Implementasi pada program yang ada di BMT ItQan diturunkan menjadi beberapah program yang terealisasi sampai saat ini ialah : Pembiayaan yang diberikan untuk penambahan modal kerja usaha seperti untuk pembelian bahan baku, penambahan persediaan, peningkatan omzet dll.

Pada program ini BMT ItQan telah memberikan modal usaha pada warga yang memang sudah mengajukan agar bisa membantu untuk meningkatkan usahanya agar lebih meningkat dari seblumnya. Salah satu produk usahanya ialah: produk atau segala sesuatu yang dapat ditawarkan kepada pasar untuk mendapat perhatian, dimiliki, digunakan atau dikonsumsi, yang meliputi barang secara fisik, jasa, kepribadian, tempat organisasi dan gagasan atau buah pikiran (Sofjan Assauri, 2004:200).

Setiap perusahaan dalam menjalankan aktivitas usaha, memerlukan strategi pemasaran yang pada dasarnya menunjukkan bagaimana sasaran pemasaran dari produk yang dihasilkan tersebut dapat tercapai. Produk adalah hal penting yang perlu diperhatikan dalam strategi bauran pemasaran, karena tanpa adanya produk, strategi bauran pemasaran lainnya tidak dapat dilakukan. Produk merupakan segala sesuatu yang dapat ditawarkan ke suatu pasar untuk memenuhi keinginan atau kebutuhan.

Penerapan strategi pemasaran produk pada BMT ItQan dilakukan dengan syarat yang mudah dan bagi hasil yang adil sesuai dengan Syariat Islam. Produk yang ada sesuai dengan kebutuhan para pengusaha UMKM, dan kemudahan yang diberikan bagi setiap nasabah yang ingin menjadi nasabah BMT ItQan.

Harga merupakan satu-satunya unsur marketing mix yang menghasilkan penerimaan penjualan, sedangkan unsur lainnya hanya unsur biaya saja. Walaupun penetapan harga merupakan persoalan penting, masih banyak perusahaan yang kurang sempurna dalam menangani permasalahan penetapan harga tersebut. Karena menghasilkan penerimaan penjualan, maka harga mempengaruhi tingkat penjualan, tingkat keuntungan, serta share pasar yang dapat dicapai oleh perusahaan. 
Dalam penetapan harga dalam hal ini biaya administrasi yang ditetapkan oleh BMT ItQan tidak memberatkan nasabah yang ingin menjadi mitra BMT ItQan. Dan biaya administrasi tersebut sesuai dengan Syariat Islam.

Distribusi merupakan kegiatan penyampaian produk sampai ke tangan si pemakai atau konsumen pada waktu yang tepat. Oleh karena itu, kebijakan distribusi merupakan salah satu kebijakan pemasaran terpadu yang mencakup penentuan saluran pemasaran (marketing channels) dan distribusi fisik (physical distribution). Kedua faktor ini mempunyai hubungan yang sangat erat dalam keberhasilan penyaluran dan sekaligus keberhasilan pemasaran produk perusahaan. Efektivitas penggunaan saluran distribusi diperlukan untuk menjamin tersedianya produk di setiap mata rantai saluran tersebut. (Sofjan Assauri, 2007: 223-234)

Mengenai strategi ditribusi yang dilakukan oleh BMT ItQan adalah dengan cara mendatangi para nasabah, dalam hal ini pedagang-pedagang pasar, kemudian pihak BMT ItQan menjelaskan tentang produk UMKM yang ada di BMT ItQan. Dengan adanya pihak BMT yang mendatangi nasabah dapat mempermudah nasabah yang ingin menjadi mitra BMT ItQan.

Promosi yang dilakukan oleh BMT ItQan dalam mengembangkan UMKM di Cicaheum adalah dengan cara: Menawarkan produk UMKM kepada nasabah atau mitra secara langsung, Membuat brosur dan spanduk dengan tampilan semenarik mungkin, dengan susunan layout brosur dan spanduk yang mengunakan tata warna, desain, kata-kata dan grafis yang baik agar menimbulkan kesan eksklusif, sehingga nasabah atau mitra tertarik untuk membaca.

Strategi ini untuk memberikan pemahaman bagi para usaha yang memang kurang mengetahui tentang strategi ini, agar lebih mudah peningkatan dalam usahanya. Contoh dari pada usaha yang terlaksana yang mengikuti Pembiayaan modal usaha BMT ItQan ialah: Lumpia Goreng, Pememberian modal usaha pengusaha lumpia goreng berupa mesin dan bahan baku sebesar Rp. 5.000.000, dan sampai saat ini usaha lumpia goreng masih berjalan dengan baik bahkan permintaan produksi semaskin meningkat setelah diberikan modal usaha di BMT ItQan, Warung Kecil-menengah Warung yang diberikan modal usaha ada 19 warung, pemebrian modal usaha sebesar Rp. 850.000/warung, dari 19 warung yang diberikan modal usaha hanya ada 3 warung yang berjalan dengan baik usaha dan angsurannya, namun banyak juga warung yang kurang baik dan tidak bisa melanjutkan usaha dan angsurannya yaitu sebanyak 16 warung. Peternakan DombaDimana peternakan domba ini sudah berjalan hampir 4 tahun, lokasi peternakan ini di Cikalong wetan Kabupaten Cianjur alsan pemilihan tempat ini dikarenakan tempat yang memadai untuk menjalankan pogram ternak domba. BMT ItQan telah bekerja sama dengan salah satu warga agar dapat menjalankan ternak domba, dan memberikan kepercayaan kepada Bapak Endang sebagai kordinator program tersebut. Dan diberikan fasilitas kandang domba yang sangat layak, domba 40 ekor, dan pangan ternak setiap bulannya. Pada akhirnya program 
tersebut semakin berkembang setiap tahunnya.

Dana zakat yang digulirkan kepada penerima manfaat, dicicil setiap bulan selama 10 bulan, hal ini dilakukan untuk melatih kesungguhan para penerima manfaat, bahwa dana yang disalurkan betul-betul harus dipertanggung jawabkan. Meskipun nantinya akan di kembalikan lagi untuk pemberian modal usaha lanjutan, a) Simpanan sebagai tanda keanggotaan Koperasi BMT ItQan, besarnya Rp. 1,1000,- (Sebelas Ribu Rupiah). Besaran simpanan ini relatif kecil sebagai komitmen manajemen koperasi untuk memberi kesempatan terutama kepada masyarakat tidak mampu agar menjadi anggota koperasi dan merasakan manfaat menjadi anggota koperasi, b) Simpanan yang diwajibkan kepada setiap anggota yang besarnya Rp. 5.000,- (Lima Ribu Rupiah) setiap bulan. Umumnya simpanan ini digabung dengan angsuran pembiayaan, c) Simpanan yang besarnya tidak ditentukan, akad yang digunakan adalah akad Wadiah Yad Dhomanah, atau titipan dimana simpanan ini bisa diambil sewaktu-waktu. Untuk pembiayaan kumpulan ada Program MENTARI (Menabung Setiap Hari), yaitu program yang dibuat agar anggota mempunyai kebiasaan menabung dengan menyisihkan minimal Rp. 1000 setiap hari.

Simpanan yang waktu pengambilannya sesuai perjanjian yang disepakati. Tersedia dalam 4 pilihan jangka waktu, 3 bulan, 6 bulan, 12 bulan, dan 24 bulan. Simpanan ini menggunakan akad Mudharabah, atau Bagi Hasil. Nasabah akan mendapatkan bagi hasil dari pendapatan bmt BMT ItQan setiap bulan, yang akan dimasukkan ke dalam rekening SIRELA ItQan.

Simpanan yang dimasukan sebagai modal koperasi, mendapatkan SHU setiap Tahun yang lebih besar dibandingkan SIMPOK dan SIMWA.

Simpanan yang waktu pengambilannya sesuai perjanjian yang disepakati. Tersedia dalam 4 pilihan jangka waktu, 3 bulan, 6 bulan, 12 bulan, dan 24 bulan. Simpanan ini menggunakan akad Mudharabah, atau Bagi Hasil. Nasabah akan mendapatkan bagi hasil dari pendapatan bmt BMT ItQan setiap bulan, yang akan dimasukkan ke dalam rekening SIRELA ItQan.Simpanan Khusus (SIMSUS) Simpanan yang dimasukan sebagai modal koperasi, mendapatkan SHU setiap Tahun yang lebih besar dibandingkan SIMPOK dan SIMWA

\section{Hasil Implementasi Program Pengelolaan Dana Zakat Dalam Meningkatkan UMKM Cicaheum Kota Bandung}

Jadi strategi pengelolaan dana pada BMT ItQan dengan cara, dana yang ada di BMT ItQan ini dipisahkan menjadi dua, yaitu Bait Al Mal dan Baitul Tamwil. Dana Bait Al Mal diperoleh dari zakat, infaq, shadaqah dan lainnya sedangkan dana Baitul Tamwil diperoleh dari dana simpanan.

Dari hasil strategi yang ada di BMT ItQan itu lumayan signifikan dalam mengembangkan UMKM, karena banyak sekali usaha yang berkembang khususnya di Cicaheum dikarenakan dampak dari adanya program-program kreatif yang dimiliki BMT ItQan. Salah satunya ialah pemberian modal kerja, dimana pemberian modal kerja itu sangat mudah mengajukannya sehingga masyarakat mengikuti program itu dan termotivasi untuk bisa menstabilkan 
Yhogie Rhanwa Soegiar Jr, Nanih Machendrawaty, \& Yuliani

ekonomi keluarganya.

Setiap bulannya BMT ItQan telah mengeluarkan untuk pemberian modal usaha, berupa bahan baku sebesar 5 juta. Salah satunya pemberian modal usaha untuk usaha lumpia gulung yang dijadikan kudapan enak, dan sampai saat ini masih berjalan dengan baik. Bahkan permintaan produksi semakin meningkat setelah diberikan modal usaha dari BMT ItQan, berupa mesin pengering minyak.

Adapun untuk warung kecil-menengah yang diberikan bantuan modal usaha ada 19 warung, pemberian modal usaha sebesar 850.000 pada setiap warung. Dari 19 warung yang diberikan modal usaha, hanya ada 3 warung yang berjalan dengan baik usaha dan angsurannya, namun banyak juga warung yang kurang baik, yakni tidak bisa melanjutkan usaha dan angsurannya sebanyak 16 warung.

Hal-hal yang mempengaruhi BMT ItQan dalam mengembangkan UMKM di Cicaheum dapat dilihat dari aspek manajemen, aspek lingkungan dan sosial budaya. Dari aspek manajemen, Pengelolaan serta mekanisme setiap produk dijalani sesuai dengan ketentuan yang ada. Banyaknya para pedagang yang menjadi nasabah BMT ItQan, baik nasabah simpanan atau pun nasabah pembiayaan sangat mempengaruhi pendapatan BMT ItQan. Semakin banyaknya para pengusaha UMKM yang menjadi nasabah BMT ItQan, maka semakin banyak pula dana yang dialokasikan untuk pembiayaan. Dari aspek lingkungan, BMT ItQan lokasinya dekat dengan pasar dan disekitarnyapun banyak terdapat pedagang-pedagang maka para pedagang tersebut dapat dengan mudah menjadi nasabah BMT ItQan karena lokasi yang dekat. Dan dari aspek sosial budaya, karena masyarakat di sekitar BMT ItQan adalah masyarakat yang memiliki tingkat religiusitas yang tinggi. Pengetahuan mereka tentang haramnya riba dapat mempengaruhi mereka dalam menjalankan aktifitas ekonominya agar tidak bersentuhan dengan riba. Selain itu, setiap orang memiliki kecenderungan untuk memilih sesuatu yang mudah dalam hal apapun. Karena itulah, ketika BMT ItQan hadir dengan menjalankan prinsip Syariah dan memberikan kemudahan secara menyeluruh, baik dalam hal produk maupun pelayanan, banyak masyarakat yang memiliki usaha tertarik untuk menjadi nasabah BMT ItQan.

Dana zakat yang digulirkan kepada penerima manfaat, dicicil setiap bulan selama 10 bulan, hal ini dilakukan untuk melatih kesungguhan para penerima manfaat, bahwa dana yang disalurkan betul-betul harus dipertanggung jawabkan. Meskipun nantinya akan di kembalikan lagi untuk pemberian modal usaha lanjutan.

Simpanan sebagai tanda keanggotaan Koperasi BMT ItQan, besarnya Rp. 1,1000,- (Sebelas Ribu Rupiah). Besaran simpanan ini relatif kecil sebagai komitmen manajemen koperasi untuk memberi kesempatan terutama kepada masyarakat tidak mampu agar menjadi anggota koperasi dan merasakan manfaat menjadi anggota koperasi.

Simpanan yang diwajibkan kepada setiap anggota yang besarnya Rp. 5.000,(Lima Ribu Rupiah) setiap bulan. Umumnya simpanan ini digabung dengan angsuran pembiayaan. 
Simpanan yang besarnya tidak ditentukan, akad yang digunakan adalah akad Wadiah Yad Dhomanah, atau titipan dimana simpanan ini bisa diambil sewaktuwaktu. Untuk pembiayaan kumpulan ada Program MENTARI (Menabung Setiap Hari), yaitu program yang dibuat agar anggota mempunyai kebiasaan menabung dengan menyisihkan minimal Rp. 1000 setiap hari.

Simpanan yang waktu pengambilannya sesuai perjanjian yang disepakati. Tersedia dalam 4 pilihan jangka waktu, 3 bulan, 6 bulan, 12 bulan, dan 24 bulan. Simpanan ini menggunakan akad Mudharabah, atau Bagi Hasil. Nasabah akan mendapatkan bagi hasil dari pendapatan bmt BMT ItQan setiap bulan, yang akan dimasukkan ke dalam rekening SIRELA ItQan.

Simpanan yang dimasukan sebagai modal koperasi, mendapatkan SHU setiap Tahun yang lebih besar dibandingkan SIMPOK dan SIMWA.

Simpanan yang waktu pengambilannya sesuai perjanjian yang disepakati. Tersedia dalam 4 pilihan jangka waktu, 3 bulan, 6 bulan, 12 bulan, dan 24 bulan. Simpanan ini menggunakan akad Mudharabah, atau Bagi Hasil. Nasabah akan mendapatkan bagi hasil dari pendapatan bmt BMT ItQan setiap bulan, yang akan dimasukkan ke dalam rekening SIRELA ItQan.Simpanan Khusus (SIMSUS) Simpanan yang dimasukan sebagai modal koperasi, mendapatkan SHU setiap Tahun yang lebih besar dibandingkan SIMPOK dan SIMWA

\section{PENUTUP}

Setelah penulis mengadakan penelitian terhadap strategi pengelolaan dana zakat BMT ItQan dalam mengembangkan Cicaheum Kota Bandung, dan berdasarkan uraian yang penulis uraikan dari hasil penelitian tersebut bahwa strategi yang dilakukan BMT ItQan dalam mengembangkan UMKM di Cicaheum adalah dengan melakukan strategi pada produk dengan cara penerapan syarat yang mudah dan bagi hasil yang adil. Produk yang ada sesuai dengan kebutuhan para pengusaha UMKM, dan kemudahan yang diberikan bagi setiap nasabah yang ingin menjadi nasabah BMT ItQan. Strategi pada harga, dalam hal ini biaya administrasi yang ditetapkan oleh BMT ItQan tidak memberatkan nasabah yang ingin menjadi mitra BMT ItQan. Strategi distribusi dan promosi yang dilakukan dengan cara memberikan brosur dan menjelaskannya pada para pedagang yang ada di pasar sekitar BMT ItQan dan menjemput jika nasabah ingin melakukan pembayaran cicilan, tabungan atau melakukan transakasi lainnya.

Implementasi dari strategi pengelolaan dana zakat BMT ItQan dalam mengembangkan UMKM adalah melalui program yaitu, Pemberian Modal Usaha, Simpanan, dan Simpanan Investasi. Dari hasil strategi yang ada di BMT ItQan itu lumayan signifikan dalam mengembangkan UMKM, karena banyak sekali usaha yang berkembang khususnya di Cicaheum dikarenakan dampak dari adanya program-program kreatif yang dimiliki BMT ItQan. Salah satunya ialah pemberian modal kerja, dimana pemberian modal kerja itu sangat mudah mengajukannya sehingga masyarakat mengikuti program itu dan termotivasi untuk bisa menstabilkan ekonomi keluarganya. 
Yhogie Rhanwa Soegiar Jr, Nanih Machendrawaty, \& Yuliani

\section{DAFTAR PUSTAKA}

A Riawan, Amin, 2009, Menata Perbankan Syariab di Indonesia. Bandung: UIN Press Agustinus, Sri Wahyudi, 1996, Manajemen Strategik, Pengantar Proses Berfikir Strategic. Jakarta: Binarupa Aksara.

Andri Soemitra, 2009, Bank dan Lembaga Kenangan Syariah. Jakarta : Kencana Prenada Media Group

Asep Iwan Setiawan, (2012). Dakwah Berbasis Pemberdayaan Ekonomi dan Peningkatan Kesejahteraan Mad'u. Ilmu Dakwab: Academic Journal for Homiletic Studies. 6(2). 347-262.

Bilson, Simamora. 2001. Memenangkan Pasar dengan Pemasaran Efektif dan Profitabel. Jakarta: PT. Gramedia Pustaka Umum

Didin Hafidudin, 2008, Zakat Dalam Pengertian Moderen. Jakarta: Gema Insani

Djazuli dan Yadi Janwari, 2002, Lembaga-lembaga Perekonomian Umat (sebuah pengenalan). Jakarta:PT. Raja Grafindo Persada.

Euis Amalia, 2007, Sejarah Pemikiran Ekonomi Islam. Jakarta: Granada Press17

Husain Umar, 2005, Riset Sumber Daya Manusia. Jakarta: Gramedia Pustaka Utama.

Irfan Sanui, 2016. Networking Badan Amil Zakat Nasional Jawa Barat dalam

Meningkatkan Pelayanan Zakat. Ilmu Dakwah: Academic Journal for Homiletic Studies. 10(1). 79-96

M. Nafarin, 2007, Pengangguran Perusahaan. Jakarta: Penerbit Salemba Empat

M. Nuriyanto al Arif, 2012, Lembaga Kenangan Syariah. Bandung: Pustaka Setia

Norman A.Hart dan John Stapleton, 2005, Kamus Marketing. Jakarta: Bumi Aksara,

Pusat Pengkajian dan pengembangan Ekonomi Islam(P3EI), 2008, Ekonomi Islam. Jakarta: Universitas Islam Indonesia Yogyakarta atas kerjasama dengan bank Indonesia

Ruslan, Rosady, 2010. Metode Penelitian, Public Relation dan Komunikasi. Jakarta: PT. Raja Grafindo Perseda

Stephen P. Robbins, 2009, Orgaizationtal Behavior. Pearson

Syafii Antonio, 2002, Bank Syariab: Analisis Kekuatan, Peluang, Kelemahan,dan Ancaman. Jakarta: Ekonisia.

Syaikh Muhammad Bin Shalih Al-Ustmani, 2008, Fatwa-fatwa Zakat. Jakarta: Darussunnah Pres 